\title{
Cystoperitoneal Shunting after Fenestration of an Enlarging Arachnoid Cyst
}

\author{
Ik-Chan Jeon, Min-Su Kim, Seong-Ho Kim, Sung-Ho Jang* \\ Department of Neurosurgery and ${ }^{*}$ Department of Rehabilitation Medicine, \\ College of Medicine, Yeungnam University, Daegu, Korea
}

\begin{abstract}
- Abstract -
A two-month-old girl with a history of an incidental arachnoid cyst in the prenatal period (38 weeks) presented with persistent irritability. A follow-up computed tomographic (CT) scan revealed an enlarged arachnoid cyst with hydrocephalus. We performed craniotomy and fenestration, but the cyst size did not decrease, and hydrocephalus had worsened on a follow-up CT scan performed 13 months after fenestration. The patient was treated with cystoperitoneal shunting. Follow-up magnetic resonance imaging (MRI) performed 5 years later revealed that the arachnoid cyst had decreased in size and that the hydrocephalus had resolved. Enlarging arachnoid cysts are not common, and optimal surgical treatment is uncertain. Based on the features of this case, we believe cystoperitoneal shunting is an advisable surgical intervention for patients with enlarging arachnoid cysts presenting with hydrocephalus.
\end{abstract}

Key Words: Arachnoid cyst, Hydrocephalus, Cystoperitoneal shunting, Fenestration

Introduction

Intracranial arachnoid cysts are lesions occupying the intracranial space that typically remain stable in size on serial imaging. Cysts found incidentally on computed tomographic scan (CT) scan or magnetic resonance imaging (MRI) do not require intervention nor do those that are symptomatic. However, surgical treatment is usually indicated for patients with focal neurologic deficits or cysts that are increasing in

책임저자 : Seong-Ho Kim, Department of Neurosurgery, College of Medicine, Yeungnam University, Daemyungdong 317-1, Namgu, Daegu, South Korea

Tel: (053) 620-3790, Fax: (053) 620-3770, E-mail: shkim@med.yu.ac.kr 
size. $^{1-6)}$ Common treatment options for intracranial arachnoid cysts include open or endoscopic fenestration of the cyst into the cerebrospinal fluid spaces and shunting of the cyst's contents extracranially, although this particular surgical method remains controversial. $^{7-9)}$

Enlarging arachnoid cysts are particularly rare, and their treatment has not been established. We report a rare case of an enlarging arachnoid cyst with hydrocephalus successfully treated with cystoperitoneal shunting.

\section{Case Report}

A 2-month-old girl had presented with an

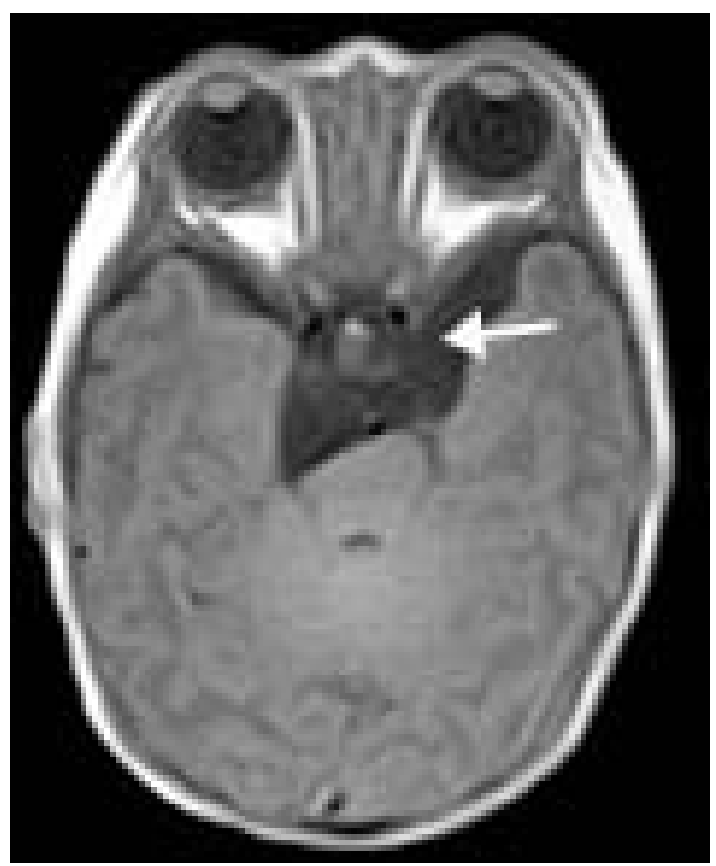

Fig. 1. Arachnoid cyst at left temporal area on magnetic resonance imaging (at birth) incidental arachnoid cyst on a routine fetal sonogram examination performed in the prenatal period (38 weeks). She had been born via a normal vaginal delivery, weighing $2.4 \mathrm{~kg}$ after 38 weeks'gestation, and was noted to be neurologically normal at that time. An MRI performed immediately after birth revealed an arachnoid cyst in the left temporal and suprasellar areas(Fig. 1). A follow-up CT scan was performed 2 months after birth because of developmental delay and increasing irritability. Imaging demonstrated that the cyst had become enlarged, and hydrocephalus had developed, making the left temporal lobe smaller than the right one(Fig. 2).

The patient underwent a craniotomy and removal of the cyst wall with fenestration.

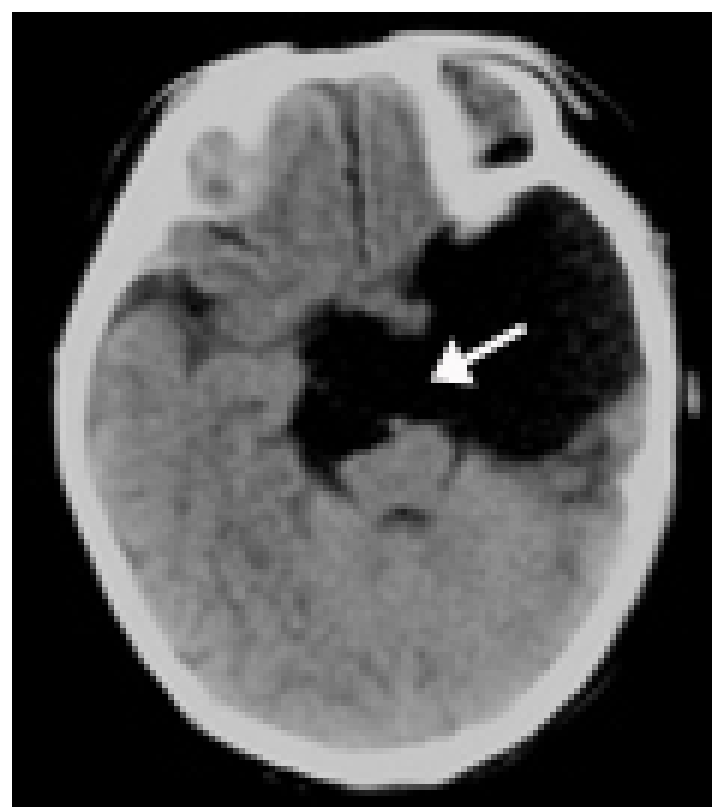

Fig. 2. Increased size of arachnoid cyst with hydrocephalus on computed tomographic scan at 2 months. 


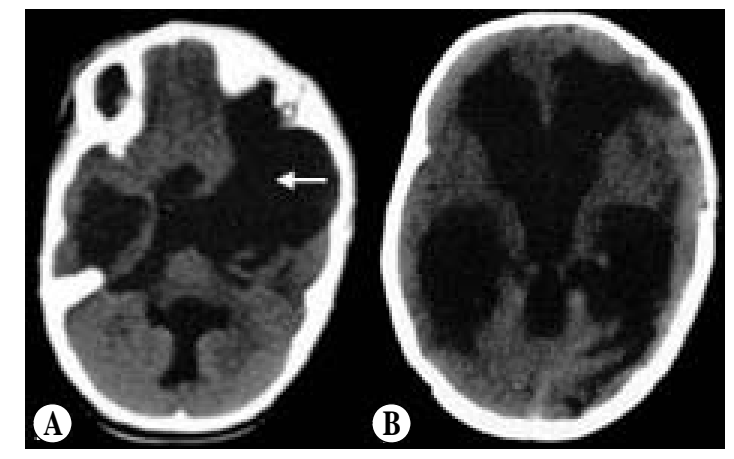

Fig. 3. Six months after fenestration. Enlarged size of cyst (A) and ventricle (B) on computed tomographic scan.

The patient did well for one month. She emigrated to a foreign country with her family, and follow-up was discontinued. Six months later, she manifested gradually increasing irritability and developmental delay. A follow-up CT scan showed increased cyst size, severe hydrocephalus, and a growing skull fracture(Fig. 3). The patient was subsequently treated with cystoperitoneal shunting. A follow-up MRI obtained after five years revealed that the arachnoid cyst had decreased in size and the hydrocephalus

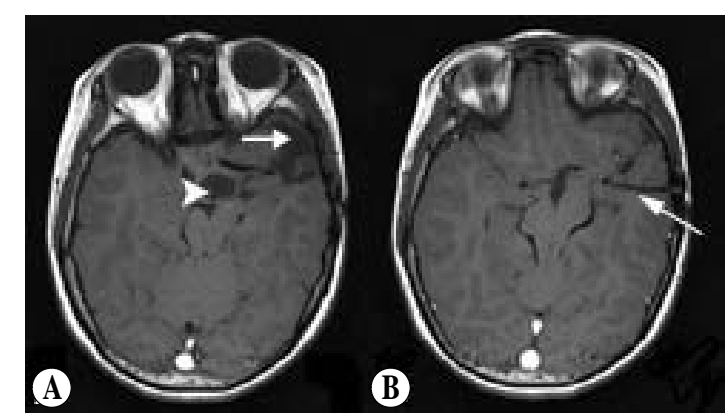

Fig. 4. Five years after cystoperitoneal shunting, magnetic resonance imaging reveals proximal shunt catheter (B) into the cyst and decreased size of arachnoid cyst (A, arrow) and ventricle (B, arrow head). had resolved(Fig. 4).

\section{Discussion}

The present patient had an enlarging arachnoid cyst with hydrocephalus, which we treated with fenestration and cystoperitoneal shunting. Most arachnoid cysts remain stable in size over time. To our knowledge, enlarging arachnoid cysts are not commonly reported in the literature, and the long-term clinical course following surgical treatment is unknown.

The etiology of enlarging arachnoid cysts is unclear. In explaining the expansion mechanism of a primary arachnoid cyst, several theories have been reported. First, the development of an arachnoid cyst may be caused by partial temporal lobe agenesis. $^{10,11)}$ Second, fluid may be secreted from the arachnoid cyst wall that contains ependymal and glial cells or from choroidlike structures within the cyst., ${ }^{4,5}$ Third, fluid ingress through the cyst wall may occur by an osmotic gradient. ${ }^{9)}$ Fourth, fluid may be trapped within the cyst with a ball-valve mechanism, ${ }^{9,12,13)}$ where minimal communication exists between the cyst and the rest of the subarachnoid space.

Rao, et al. ${ }^{6)}$ described two cases of enlarging arachnoid cysts that were successfully treated using open fenestration. One case represented a rapidly growing cyst in the middle cranial fossa found on a CT scan 6 months later. 
The other case represented an enlarging arachnoid cyst in the right frontal area found on a follow-up MRI 4 years later. Otherwise, Stein, et al. ${ }^{14)}$ reported 12 infants and children with enlarging arachnoid cysts, who were treated with shunting and fenestration. Shunting was more successful in controlling symptoms and reducing the size of the cyst.

The best surgical intervention for children with arachnoid cysts remains controversial, and the degree of cyst volume reduction correlates significantly with clinical outcome. The most common surgical treatment is open or endoscopic fenestration and shunting. Many authors suggest that the presence or absence of hydrocephalus is important in determining the surgical treatment., ${ }^{9}$ ) Patients without hydrocephalus should undergo craniotomy (or endoscopy) with resection of all easily removed cyst walls and fenestration of the cyst into all accessible subarachnoid spaces, while patients with hydrocephalus probably yield more benefit from shunting. ${ }^{14,16)}$ Cyst location is another important factor in the success of surgical treatment. Some reports have shown that middle cranial fossa cysts are usually treated with fenestration, whereas cysts in other locations are less amenable to such treatment., ${ }^{3,15)}$ Middle cranial fossa cysts are rarely associated with hydrocephalus, but posterior cranial fossa cysts are commonly associated with hydrocephalus. Moreover, suprasellar cysts are difficult to drain into the subarachnoid space.

In this case, the patient's preoperative images revealed an arachnoid cyst, which was increasing in size and which was located in the suprasellar and left temporal areas. Hydrocephalus was also present, and the patient underwent craniotomy andfenestration. A follow-up CT revealed that the cyst and concomitant hydrocephalus continued to persist. After cystoperitoneal shunting was performed, the size of the cyst decreased, and the hydrocephalus resolved. We therefore drew two important conclusions. First, we recommend follow-up neuroimaging studies for arachnoid cysts. Second, we believe that cystoperitoneal shunting may be superior to fenestration in the treatment of patients with enlarging arachnoid cysts presenting with hydrocephalus.

\section{요 약}

재태 38주에 시행한 산전 검사상 우연히 발 견된 거미막 낭종을 가지고 태어난 생후 2개월 된 여아가 지속적인 과민상태를 나타내었다. 이후 시행한 두부 전산화 단층촬영상 수두증을 동반하여 크기가 증가된 거미막 낭종이 관찰되 었다. 우리는 상기 소견에 대하여 개두술하에 낭종 개창술을 시행하였으나 낭종의 크기가 줄 어들지 않았고, 13 개월 이후에 시행한 경과관 찰에서 수두증이 악화된 소견을 보였다. 환아 는 이후 낭종-복막간 단락술을 시행하였으며, 5년뒤 시행한 두부 자기공명영상에서 낭종의 
- Ik-Chan Jeon • Min-Su Kim • Seong-Ho Kim • Sung-Ho Jang -

크기 감소와 더불어 뇌수두증이 해소되었다. 거미막 낭종 자체의 크기가 증가하는 것은 드 문 현상이며, 아직까지 이에 대한 명확한 수술 적 치료는 나와 있지 않다. 우리는 이 증례를 통하여 수두증이 동반된 크기가 증가하는 거 미막 낭종의 치료에 있어서 낭종-복강간 단락 술이 적절한 수술적 치료법이 될 것으로 판단 한다.

\section{Reference}

1. Beltramello A, Mazza C. Spontaneous disappearance of a large middle fossa arachnoid cyst. Surg Neurol 1985 Aug;24(2):181-3.

2. Choi HC, Jeun SS, Lee KS, Kim MC, Kang JK. Surgical Treatment of Middle Cranial Fossa Arachnoid Cyst by Wide Excision and Fenestration. J Korean Neurosurg Soc 2003 Jan;33(1):56-61.

3. Hanieh A, Simpson DA, North JB. Arachnoid cysts: a critical review of 41 cases. Childs Nerv Syst 1988 Apr;4(2):92-6.

4. Kumagai M, Sakai N, Yamada H, Shinoda J, Nakashima T, Iwama $T$, et al. Postnatal development and enlargement of primary middle cranial fossa arachnoid cyst recognized on repeat CT scans. Childs Nerv Syst 1986 Jul;2(4):211-5.

5. McDonald PJ, Rutka JT. Middle cranial fossa arachnoid cysts that come and go. Report of 2 cases and review of the literature. Pediatr Neurosurg 1997;26(1):48-52.

6. Rao G, Anderson RC, Feldstein NA, Brockmeyer DL. Expansion of arachnoid cysts in children: report of two cases and review of the literature. J Neurosurg 2005 Apr;102(pediatric3): $314-7$.

7. Arai H, Sato K, Wachi A, Okuda O, Takeda
N. Arachnoid cysts of the middle cranial fossa: experience with 77 patients who were treated with cystoperitoneal shunting. Nurosurgery 1996 Dec;39(6):1108-12.

8. Galassi E, Piazza G, Gaist G, Frank F. Arachnoid cysts of the middle cranial fossa: a clinical and radiological study of 25 cases treated surgically. Surg Neurol 1980 Sep;14(3): 211-9.

9. Kang JK, Lee KS, Lee IW, Jeun SS, Son BC, Jung CK, et al. Shunt-independent surgical treatment of middle cranial fossa arachnoid cysts in children. Childs Nerv Syst 2000 Feb;16(2):111-6.

10. Geissinger JD, Kohler WC, Robinson BW, Davis FM. Arachnoid cysts of the middle cranial fossa: surgical considerations. Surg Neurol 1978 Jul;10(1):27-33.

11. Robinson RG. The Temporal Lobe Agenesis Syndrome. Brain Mar 1964;87(1):87-106.

12. Caemaert J, Abdullah J, Calliauw L, Carton D, Dhooge C, van Coster R. Endoscopic treatment of suprasellar arachnoid cysts. Acta Neurochir (Wien) 1992;119(1-4):68-73.

13. Schroeder HW, Gaab MR. Endoscopic observation of a slit-valve mechanism in a suprasellar prepontine arachnoid cyst: case report. Neurosurgery 1997 Jan;40(1):198-200.

14. Stein SC. Intracranial developmental cysts in children: treatment by cystoperitoneal shunting. Neurosurgery 1981 Jul;8(6):647-50.

15. Raffel C, McComb JG. To shunt or to fenestrate: which is the best surgical treatment for arachnoid cysts in pediatric patients? Neurosurgery 1988 Sep;23(3):338-42.

16. Ciricillo SF, Cogen PH, Harsh GR, Edwards MS. Intracranial arachnoid cysts in children. A comparison of the effects of fenestration and shunting. J Neurosurg 1991 Feb;74(2): $230-5$. 